\title{
Organizational entrepreneurship, politics and the political
}

\author{
Carine Farias, Pablo Fernandez, Daniel Hjorth, Robin Holt
}

Entrepreneurship as organization creation

As the creation of new organizational forms and, indeed, new organizations, entrepreneurship challenges the settled, institutionalized and habituated nature of what already has been organized. "The interaction of institutional forms and entrepreneurial activity, the 'shaping' influence of the former and the 'bursting' influence of the latter, is, as has already been intimated, a major topic for further inquiry." (Schumpeter 1947/1991: 225) By assuming and proposing that one can act with others in pursuit of opportunity or even create opportunities, the entrepreneurial move takes place in-between or along the edge of established human practice. This time and space between 'what is' and 'what could become' means entrepreneurial action often publicly brings people to the fringe of action, to habits, tradition and custom, making them aware of what Schumpeter called the 'pale of routine.' It is in summoning collective desire and directing enough force for making this move toward what lies beyond the fringe attractive enough that we witness entrepreneurship as an organizational creation process (Schumpeter 1947/1991).

Such a process is only provisional, as once new organizational realities form recognized entities, once they have achieved their process of becoming, they convert 
into a part of the structure, drifting towards what Rancière would call "the police" that is, a symbolic and definite constitution of the social. Here it is soon guarded by dominant discourses, made investments, habits and routines. This is Schumpeter's (1947/1991: 229-231) message when he suggests that the opening of new space for creation will eventually 'yield its place to the teamwork of specialists...' for free movement will always be subject to classification, making it predictable (Hirschman 1977) and thus controllable with reference to a managerial economy of efficiency. Entrepreneurship as the creation of new firms inevitably has to also become management; revenues and profits are necessary for a continued capacity for free movement. Even when the movement of organization-creation breaks out from the efficiency regime - as is the case for alternative organizations for instance - its survival still depends on on broader structures of classification into which the new organizational form is pitched. This 'pitching' generally results in implosion and dispersion: some elements of the 'new' simply disappear, while others are named and absorbed by the structure. The challenge is precisely this 'both-and' that has proven to be difficult, political and one reason why organisational entrepreneurship is a rare phenomenon in large, old firms (Schumpeter 1947/1991; Sørensen 2007; Kacperczyk 2012).

In this special issue, our focus is primarily on the opening up, the move away, the declassification, the entrance of the unthought into action as free movement without denying the need for such processes to become well-managed ones, securing economic capacity for the politics of new action - freeing entrepreneurship again from its policing state of being classified into proper space. That is, we want to rehabilitate and understand further the inherently political dimension of organizational entrepreneurship; the process of organizational creation opens-up spaces in which 
entrepreneurs express their voices and shape the redistributions of resources and attention, altering what it is to say and do things meaningfully, legitimately and with authority.

\section{Enterprise}

In this association of entrepreneurship and organization-creation we find a growing awareness that the entrepreneurial is not synonymous simply with economic enterprise, despite their frequent association (Hjorth and Holt 2016; Courpasson, Dany and Martí 2016). Indeed, we might argue this assumed association of entrepreneurship and the economic is itself a political move motivated by the need for governable citizens: "[T] he belief that [economic] interest could be considered a dominant motive of human behavior caused considerable intellectual excitement: at last a realistic basis for a viable social order had been discovered." (Hirschman, 1977: 48). Enterprise associates specific organizational structures (ventures, markets), human qualities (risk taking, boldness, self-reliance), norms of social and economic deregulation (individualism, profit seeking, competition), and certain effects (scaled innovation, profit, acquisition, social mobility, wealth creation), all of which is couched in a language of material resuscitation and growth (Anderson and Warren 2011; Dodd et al. 2013; du Gay 2004; McNay 2009; Parker 2002; Sturdy and Wright 2008). Here the locus of curiosity and inquiry so valued by enterprise is framed by a politics of homo oeconomicus agents living in competition-based individuality, deciding whether, on a basis of a normative recognition of shared needs, to build relationships with one another (Massumi 2002), all the while finding whatever they touch - their dreams, their family, their conversations - mediated into forms of capital (things which could be invested in to bear future returns (Becker 1995; Chun 2019). 
Such individuality is not naturally occurring. Homo oeconomicus was never meant as an empirical description, but rather as a theoretical fiction, a construct that enables economics to operate as applied mathematics. This, however, is also the normalisation of a measured life (e.g. biology, economics), which means that humans can always be reduced from a political being (bios life) with rights to rights, into this measured life (zoe), a bare life where we may have rights (Agamben 1998) and can therefore also always be included only as excluded, as abnormal (according to dominant ways to measure life). It is sustained through academic disciplinary systems, also beyond economics, such as evolutionary biology and social psychology, through religions encouraging self-ordained work ethic of discipline and sacrifice, through state supported family values of responsibility, and through forms of market exchange whose forms of equilibrium assume similar pre-eminence to the balanced scales of blind justice (cf. Weber's work on protestant ethics). The enterprising subject has arisen from within these historically embedded structures. It is form of subjectification in which innovative, means-end thinking in the service of individually configured interests is deemed a useful, valuable and pre-eminent configuration of the human self. Here politics goes all the way, for it is not only politics which is conceptualising the struggle of one individual positioned with or against others, it is politics defining what it is to be rational, normal, autonomous, or even to count as human (Agamben 1998; Foucault 1994; 2003; 2008).

Enterprise (which pulls towards zoe, measured life), often disguised as entrepreneurship (which has a ring of whole, creative life, bios), have been woven into this dominant normality. The shapes and rhythms of organizational form attest its increasingly pervasive force. In spite of the recurring challenges targeting the politics of enterprise, and the search for more emancipatory social structures, the figure of the 
enterprising self constantly resuscitates in new organizational forms and renewed discourses. These forms are those of flattened hierarchies, energy zones, fab-labs, founders' houses, innovation hubs, and all manner of loose, playful shapes being vaunted by those for whom self-realization and creativity are twinned at birth. Yet these forms cannot exist in isolation. Accompanying them come privately owned homes purchased by families embroiled in a constant struggle to remain creditworthy; the transportation networks and global supply chains mobilizing populations into near-permanent state of transience; the retail parks in which consumers educate themselves in the demands of self-service; the schools, universities and hospitals in which excellence and value are calibrated by competitive performance metrics; the increasingly opaque regimes of regulation and taxation; the outsourcing of social welfare to private companies mediated through insurance schemes; and agile and flexible life in precarious organisations. It is this entire digitally mediated system of managed empowerment that is nurturing the independence and innovative potential of citizens under the guise of the enterprise economy; we are all, it seems, to become free (meaning work in precarious organizations, Vallas 2015; Flemming 2017) to fantasize about our impending affluence cushioned by an ethics of self-help. Enterprise is upon us, everywhere (Miller and Rose 1990; de Gay 1991; Cooper 2017; Rose 2019: 446).

Innovation has become a permanent necessity. The search for, and delight in, the new has extended from an interest in objects (engineering invention) to the social and cultural realm of creating organizational form and skill development ((self)managerial innovation) (Reckwitz 2017: 100-105). It is these entwined forces first technological invention, and second a coupling of emotionally charged, autonomous subjects for whom productive efficiency is akin to self-realization, and 
finally agile, chameleon-like organizational forms able to respond rapidly to environmental change - that constitute the enterprise economy. These technologically mediated forms of the enterprising subject and organization (working anytime, anywhere, in whatever open, networked, temporary configuration) cast a uniform image of enteprise (Hirschman 1977: 49; Hoskin 2006) where human capital models normalizing measured/bare life (Agamben’s 1998, zoe) dominate (Becker 1995; Foucault 2008; Fleming 2017). Here the social and the societal have been left outside studies of entrepreneurship (Steyaert and Katz 2004; Steyaert and Hjorth 2006), and the political has fallen outside the domain of attention for the analyst seeking to explain what is going on (Daskalaki, Hjorth and Mair 2015; Martí and Fernández 2015). Analysis recurs, for example, to the usual standard business models to explain how ventures emerge, and the social and political, where it is considered, is done so as a kind of bolt-on, an additional branch of study.

In making this omission evident and thus making-abnormal entrepreneurship as economised (measured and thus potentially normalised life, zoe) and reduced to enterprise, and in instead raising the intimacy between the enterprise economy and the political, we envisage entrepreneurship differently here. Entrepreneurship, as we define it, is the creation of new organizational forms in which the virtual becomes necessities working on the fringe of established orders, threatening as much as enhancing the enterprise economy. Entrepreneurship, we argue, in its process of opening-up and moving away, is always of this double form as a political act: it opens up established orders, often breaking enterprise solutions-at-work, and in challenging the normal, potentializes new value-creation. We can also see this as breaking the norm of a rational measured life (zoe) and opening up for a potential life, a (bios) lifeto-come, which necessitates a social and political process without which organisation- 
creation is impossible. Intensely so in the context of organization, which arguably is primarily about what is in-between and simply in people. The dawning of organizational forms in which the virtual, or what was imagined merely possible, begins to touch everyday experience as actualisation progresses, brings with it potentially destructive forces. By transgressing and involving what is "out of place" (Douglas, 2003), such creation of new organisation(al forms) is thus always accompanied by the political struggle of finding an agreeable new order.

Following Hjorth and Steyaert (2009), Zahra et al (2013), and Hjorth and Holt (2016), by stressing the connection between entrepreneurship and the political we thus emphasise the importance of not collapsing the distinction between enterprise and entrepreneurship; the latter is grounded in sociality and hence politics. Moreover, we find it artificial to try to understand entrepreneurship when the political and social are added, which would be to include it only as the excluded. We seek to understand the immanently socio-political nature of entrepreneurship (cf. ERD Special Issue 2013; Down 2013) in the context of established organizational spaces (Beyes and Steyaert 2012; Courpasson, Dany and Martí 2016).

\section{Politics and the political}

In order to reconnect entrepreneurship studies with the socio-political dimensions of organisation-creation, taking place always in the context of the already organised, we find ourselves provoked by Jacques Rancière's thought. For Rancière (2004: 60-66) the political is neither an informed and reasoned conversation between different positions nor the argumentative articulation of different interests, each vying with the other for prominence, however tentative. These conversations and interests are the stuff of what he calls an instrumental politics of positioning: the vying of voices 
in the service of vainglory. It is politics with a chosen message to sell to an audience, it is politics as branding and consuming, it is zero-sum politics where winners carry rosettes and losers nurse charred hopes, it is politics organized within the already established structures of which we have been speaking. Politics here, within established structures, is concerned more with change as quantitatively more rather than the qualitatively different. This is politics in measured life, where enterprise is fully possible to manage via systems for agile, flexible, innovative people.

In contrast to this politics comes the other part of what we have called the 'double form' of entrepreneurship, the political. When we see entrepreneurship as a more whole life, including rather than adding the social and political (and not simply economic), creation is also more complex as it strives to make the qualitatively different, the virtually new happen. The political lives before and beyond politics if the latter is understood as a more competitive-calculative game within the existing dominant order. The political process, centred in equality, would be a process of how new possibilities for living should be accomplished. When this is tied to organisationcreation, breaching the dominant order, we are dealing with the entrepreneurial. It is less organized, being the struggle to find a voice and be heard in the first place. It erupts along the fault lines lying between institutional structures and established interests (cf. Welter and Smallbone 2010). These are spaces devoid of the settled roles allotted to subjects, including those of the enterprise economy, but toward which a host of well-defined offices, procedures and norms are directed, either in fear (keeping the unruly and unmanaged at bay) or anxiety (only the organization of institutional settlements prevent us from falling into the void).

The political is always being watched and managed by politics, or what Rancière (1997) calls policing. The intent of policing is to manage the open spaces 
lying in-between the community and the already organized sum of established social groups. Policing thus defines "the ways of being, doing, and saying appropriate to these places" (Davis 2010: 78). This management (sometimes violent) is realized through classification and naming: to identify and categorize is to push back at the absences that have always constituted a threat to the social order (Douglas 2003). By naming the open spaces, policing adds to the established structure of what is already known and ordered, the political becomes subject to the business of politics. We see how this resonates with Agamben's (1998) description of a measured life, the life of bio-politics (Foucault 2008) or zoe, where the social and political life (bios) is made governable.

The political elides or refuses this naming, it is present as newness and disruption, but is all the while being overridden by a managed politics. The same for entrepreneurship, insofar as it resists the economic and ethical demand of the enterprise economy to be instrumentally innovative, and instead looks to disrupt and disturb for the sake of finding the actual in the virtual. To maintain itself along the liminal edges and fault lines, such a political condition has to be attentive not only to language, but to the far broader, historically constituted regimes of perception and sensibility within which meaning is being continually constituted and embodied. In being aware of the myriad ways subjects are expected to behave - e.g. as woman, as entrepreneur or entrepreneurial employee - disturbs these distributions by clouding the apparently clear division between those who act and those being acted upon, between those who manage and are managed. The everyday policing habits of politics are made apparent, and being so are exposed to questionability in active attempts at disturbing the distributions of the sensible (Rancière 2004: 40-47) as the system of selfevident facts of sense perception that at any point in time makes us see and experience 
the common world in a certain way. Rancière places the sensible in his view of the political, since he believes aesthetics - what determined how forms are presented to sense experience, what is visible and invisible, what is mere noise and what is speech is at the basis of the politics (Rancière 2004). Such a common world is also maintained by the delimitations and allocations that define positions and grouped within it. In the world of existing, mature and large organisations, management is a position within the dominant normality (Burnham 1941; Burgelman 1983; Kanter 1989; Sørensen 2007; Kacperczyk 2012) and entrepreneurship has historically only been included in an excluded position (a state of exception, an abnormality). Rancière therefore describes the political as a declassification of one's proper place in this police order. Declassification is to 'undo the supposed naturalness of orders' (May 2009: 112). To belong in such politics, in the measured and classified categories of those who can/have, are seen and heard, or not, is to be subjugated to directed, sometimes well-meaning managerial attention, and more broadly the prevailing operations of power. Outside of this policed state of politics as a game of ordering the categories properly, is the political. To be political means starting with people in everyday space, revealing what it is they claim for themselves and others, without accepting the normality that the sense and facts that historically has come to determine their position would suggest. The political becomes a process not of unifying but of declassifying, of freeing oneself from already policed (named) distributions of the sensible. The political is, then, a space of the overlooked, the forgotten, the resented, the unpredictable, the lost, the faulty, the incidental and the incipient. Unsettling this order is always, though, a possibility: distributions can buckle or even transform, as organized thresholds give way under struggle (Rancière 2004: 62) for the new. 
This organizational fault line between the political and politics is configured in a space especially prone to the generative presence of creativity, which as artistic practices, for Rancière (2004: 13) are "ways of doing and making that intervene in the general distribution of ways of doing and making as well as in the relationships they maintain to modes of being and forms of visibility." For us, in this Special Issue, suggesting we see entrepreneurship as a creation process that is also political can itself be understood as a political act of declassifying and de-normalising entrepreneurship as little more than enterprise. However, beyond this attempt to change the complex apparatus that govern the distribution of sense and facts that determine the place and position entrepreneurship has in the academic disciplinary system, we want something else. We want also to make visible and 'unsilence' the political as part of the entrepreneurial creation process.

\section{The political and the entrepreneur as subject}

Rancière's sense of the political has resonance with our above elaboration of entrepreneurship as that force which is always in tension with the already organized, established, and normalized. Entrepreneurial creations are of a double nature: in ways conforming to the prevailing orders of politics whilst also nurturing, accidentally or deliberately, the political. In this way entrepreneurship steps outside enterprise (which is an ordering of politics). Entrepreneurship, or "entreprendre" in French, as we have heard before (Chia 1996), consists in "grasping, seizing" (prendre) what is "in-between" (entre). That is, entrepreneurship plays with the cracks in the distributions of the sensible to, potentially, produce new orders from what is not-yet-existent. By disturbing and expanding these distributions of the sensible, entrepreneurship can be understood as also a political process. Policing is the management of people in 
categories through acts that (re)establish order, assign roles and places for actors, including the visibility/invisibility and voice/noise that belong to those roles/places, while the political is the enacting of multiplicity and openness by bringing dissensus. In Rancièrian terms, that policing gradually takes over the political translates into the tendency of management to take over entrepreneurship by ordering it into the category of enterprise (preferably disguised as entrepreneurship).

Therein lies our basis for seeing entrepreneurship as also inevitably political. Entrepreneurship, in the sense of organization-creation, is a constant attempt at declassifying existing structures and institutions, de-normalising practices and sensemaking, to make room for and initiate the new. The policing impact of the 'already-organized' upon organization-creation processes means entrepreneurship is always a political process. Entrepreneurship is about those creations as yet missing from dominant orders, about those who are underway in spans of creative, collectively woven 'blocs of becoming' that (temporarily) breach the instrumental framing of an enterprise economy under a compulsion that life might somehow be organized differently (Massumi 2015). This is the political process breaking away from the police. This difference, added multiplicity and heterogeneity, achieved newness, is actualized through collective organizational action. In our attempt to better understand the nature of such processes of organizational entrepreneurship, creating the conditions for the new to achieve being, this special issue stresses the need to see entrepreneurship as inherently political as much as it is necessarily bound up with politics.

Entrepreneurship as political would thus have to be understood as a break of consensus, the transgressive and conflictual disruption of the distributions of the sensible that is bound tightly to the subject-positions and the in/visibility and 
noise/voice that define them. Entrepreneurship's political (operates by subverting the order as it "revolves around what is seen and what can be said about it, around who has the ability to see and the talent to speak, around the properties of spaces and the possibilities of time.” (Rancière 2004: 13). In Rancière's terms, the political brings the "reconfiguration in the here and now". And this reconfiguration is embodied in the work of the individual (or the group) that distances it/him/herself from the order of the sensible that belongs to the reigning classification, the proper place to be in, to become a political subject. Entrepreneurship can thus be understood as a 'disruptive event' (Hjorth and Steyaert 2009), meaning that it moves beyond present boundaries to create space and de-classify/de-normalise. Such critical work sets free (who is seen, who can speak, who can have access) in order to enter the concrete and passionate work of affirming the abnormal or new (Ibid., p. 4). The process of reconfiguring the individual (subjectification, Foucault 1982; Butler 1997; Deleuze 1995) is "the production through a series of actions of a body and a capacity for enunciation not previously identifiable within a given field of experience..." (Rancière 1999: 35). Importantly, any subjectification implies a dis-identification, a "removal from the naturalness of a place, the opening up of a subject space ..." (Ibid., p. 36). This would involve freeing ourselves from a subjectivity assigned for us in the place proper that corresponds to the category we are in, and the order that is policed in that dominant politics. What happens when these orders are challenged, when we do-naturalise and de-normalise, is that the time of subjectification arrives (Deleuze 1995). It can be affirmed or negated. If affirmed, a becoming starts, possible to describe as play since it is not within but beyond normalised orders. This is entrepreneurship as political process of creating new organisation. 


\section{Entrepreneurship, creativity and the open/common}

In the enterprise economy open spaces are constantly subject to policing. They are named 'innovation or 'opportunity': a space in which subjects are exhorted to internalize the responsibility for their own flourishing, and to organize themselves accordingly: enhancement through skill development, mindful precarity, the variety of portfolio careers, the confidence realized through self-branding. Being a space of distributing the sensible, what counts is the technique to play with symbols, perceptions and affects so as to generate novelty. And, as Reckwtiz (2017: 124-127) notices, in the enterprise economy, it is a peculiar form of novelty: where in the past, in Schumpeter's time, the emphasis of creative destruction was on the technical innovation in objects and processes so that one state is deemed to improve upon an earlier one (professional development, practical problem solving), now the emphasis is upon difference for its own sake (desire and enjoy this); 'better' gives way to 'individual' (understood as unique). This makes the politics of new organizational forms increasingly dependent upon engaging an audience. In such an enterprise economy those creating new organizational forms are deemed by investors to be creative people who, in the company of aesthetic tools, produce sensory and affective experience for consumers who are themselves, increasingly, encountered as enterprising, replete with their own self-guiding desires to co-produce value with the producer.

Enterprises no longer see themselves primarily as self-guided centres of production, because they are fundamentally dependent on the unpredictable attention of an aesthetically oriented consumer public (Reckwitz 2017: 91). 
Thus, policing takes on a creative hue: mediating structures (digital platforms; structuring of investment capital; start-up support; acceleration coaching) are found to purposively frame what is fast becoming an experiential-based economy in which producers and consumers co-constitute the conditions of their mutual self-expression, time after time after time, in ways that secure capital return.

To be entrepreneurial, in contrast, is to both belong to the common and yet to disrupt the positions of subjectivity being made available here, whether those of producers or consumers, by refusing the demand for constantly achieving individual fulfilment through becoming-subjectified in prefabricated ways. This is how the open is created in the common. This is also where the political starts: when what is not given in the common as the already distributed sensible instead starts to play in the opening, and allows a redistribution of the sensible to happen. Entrepreneurship is identified as such a disruptive event, a temporary opening in the common, or at the fringe of the common, enabling new facts and new sense to emerge. It is temporary as policing will also try to make use of such openings in order to re-establish the politics of the dominant order.

Becoming-entrepreneurial in organisational contexts seems to necessarily start with affirming and resisting the subjectivity of the enterprising employee. Today, normality includes the enterprising employee. It means that becomingentrepreneurial is a liminal process in this sense of seeking for cracks to expand in the order of the dominant politics. The entrepreneurship process is thus also political in that it occupies the fringes in distributions of the sensible, where also policing operates and rewards behaviour that performs a certain script, and speaks the right language opportunity. Although it might be more obvious in the case of organisational entrepreneurship (corporate entrepreneurship, intrapreneurship, corporate 
venturing), entrepreneurship is always bound to participate in the common. This is where the presently dominant form of distribution of the sensible is reproduced and kept in place. Whether entrepreneurship disrupts by using cracks in this normality, or by imagining new ways to think and be, creation of the new will always change this order (if ever so little). Value beyond efficient use of existing resources (which can be achieved by the quantitatively more and thus not threaten the politics of the dominant order), found in the qualitatively different, will always upset, disrupt and be political. Seeking to disclose the political in the entrepreneurial, this Special Issue has suggested we see entrepreneurship as part of the common, but drawn towards its potential openings or drawn towards its limits, beyond which the open lies. This means entrepreneurship, also the subjectivity of entrepreneur, is an ambivalent and fragile position. It is a grey-zone life, or the yellow light of the in-between (in-between green and red, using the traffic light metaphor). Entrepreneurship has to know the politics of the dominant order of the common, yet move from there to the open, where it is exposed to normalising attempts. To partake in the common entrepreneurs, as much as they avoid the conspicuous ordering of management, also eschew and elide the positions of subjective innovation and creativity being made available in enterprise economy. They realize neither position corresponds to their experience of the sensible, and instead, without the comfort and protection of performing inside a classification, there is always the potential for a passionate life of struggle. This, as philosophers of creativity has proposed, holds the joy of the speculative affirmation of becoming (Deleuze 1988), never guaranteed, always playfully in-between.

\section{The papers in the special issue}


This special issue offers a reading of organizational entrepreneurship as an unstable and ambivalent process that constantly opens-up the common (and its common sense) to potentials for becoming-new, meaning the politics of established order will be disturbed by a proposed political redistribution of the sensible. This process is thus approached in three movements: first, entrepreneurship disrupts the politics of the dominant order through organization-creation; second, in the open/vulnerable state, existing institutional forces attempt to police the entrepreneurial processes by absorbing some elements of the new into existing structures (naming the organization a venture, requiring business plans, etc..) - the politics of measured life, rewarding change as more of the same, as quantitative; third, entrepreneurs start a process of subjectification and de-identification shaped by a constant back and forth between partaking in the common (Skoglund and Boehm, 2019) and the political struggle of creating openings, or moving into the open through which qualitative difference (becoming-new) can be achieved, but not without facing the police and the struggle with politics.

The papers by Lüthy and Steyeart (2019) and by Duymedjian, Germain, Ferrante and Lavissière (2019) are the ones to most overtly unveil the dynamics through which such a collective endeavour of organisation-creation is akin to reengaging with the political. This political dimension of entrepreneurship is conceptualized in two different but complementary ways. For Lüthy and Steyeart (2019), the participation in the struggle for the redistribution of the sensible is mainly played out through experimentation (cf. what we have called speculative affirmation above): entrepreneurs partake by challenging, disrupting established orders. Nevertheless, they explain that while there is an attempt at disrupting, this attempt should not necessarily aim at creating lasting social realities. Movement has priority, 
and for this the assemblage of the heterogenous is both disruptive and generative. Placing emphasis on the experimental in entrepreneurship, they disclose the entrepreneurial process in its socio-materiality, its embodied nature, and its processual fluidity. Again, fluid, moving, entrepreneurship resists stabilization and instead thrives in the open. Resonant with what we have discussed above, for Lüthy and Steyaert, entrepreneurship is political in the onto-political sense of creating new 'relationships through which our lives appear'. For Duymedjian et al. (2019) seek to understand the genealogy of opportunities. They use Deleuze's concept of encounter to analyse how openings in the common, in the dominant normality (as we have discussed above) are achieved. Encounters disturb the politics of the normal, which means a crack in the normal life is made and an opening to potential, to opportunity results. The concept of encounter thus helps them to study the genealogy of opportunity in a way that sensitises us to the political. The case they study - the film Dallas Buyers Club brings us into a liminal life of struggling to create new possibilities for living. This is life of conflict and tension, of battling norms and normalities, of taking chances and being forced to grasp the politics that seeks to control. 'Encounters', they write, 'will thus gradually politicize the process because they confront Ron [person in the film] with social categories he rejects.' This too resonates with the Rancière inspired approach to the political we have presented. Also the way Ron handles these categories - deal with or imitate - signals the necessity to understand what orders the common and what conditions the cracks therein or the opportunities at the margin, as we have discussed above.

We can infer from these papers that in being political entrepreneurship creates new social realities, new sets of beliefs. Once those are named, categorized, they become part of the social order. In Rancierian terms, they drift into politics. This drift 
translates into powerful discourses and aesthetic representations, asserting what should be, at the exclusion of other interpretations, other forms (as in Reckwitz's reading of the enterprise/experience economy). Here Riot (2019) reflects upon the most widespread of these representations of entrepreneurship: the emblematic figure of the Schumpeterian entrepreneur. Such a representation is rooted in specific, political worldviews (for Schumpeter, entrepreneurship supports capitalism), and as such, reinforce the police, imposing a hegemonic discourse on what entrepreneurs and entrepreneurship should be: a creative destructor.

Riot's is a subtle argument. She is aware, along with Zahra, Newey, and Li (2013: 143) and Swedberg (2012), that Schumpeter is a critical figure in arguing for an intimacy between entrepreneurship and the socio-political stretches. It often goes ignored that for Schumpeter entrepreneurial ventures were allocators of social not just economic wealth, and that as a force of allocation they were as romantic as they were rational. It is a force Schumpeter loves, and which he pines for: "[T] $]$ he romance of earlier commercial adventure is rapidly wearing away, because so many more things can be strictly calculated that had of old to be visualized..." (Schumpeter 1942: 152). So Schumpeter is alive to entrepreneurs being social and political figures, his analysis is replete with wider sensitivity to political economy. Yet for Riot (2019) the sense of political economy in which he sets his creative entrepreneurial subject is an elitist, nostalgic and contested one. It is grounded in a fear and lament that capitalism might be crocked because it has become so overly managed, leaving little room for expressive heroics of individuality. Schumpeter is, thus, advocating a different position in the broader politics of capitalism, once which rails against both Marxism on the one side and corporate forms of managed and state supported capitalism on the other. 
Rather than partaking of the political, he advocates a rival form of policing, one which resonates with much of the thinking behind the enterprise economy.

Riot's (2019) paper illustrates the ways organizational entrepreneurship can drift into the policing of politics with the emergence of a powerful and codified representation of itself. The papers by Muhr, De Cock, Twardowska, and Volkmannsee (2019) and by Jarrodi, Bureau and Byrne (2019) show how this dialogue between the political and the police is internalized and navigated by individual entrepreneurs, and translated in the unfolding of their entrepreneurial identities and activities. In the study by Muhr et al. (2019) comes the story of an entrepreneur ultimately unwilling to be subjectified by the existing categories of policing, a subject who struggled to partake (and so avoid the occupation of one position or another), but who nevertheless remained an active and engaged subjective force, someone who in Rancière's terms is taking part politically yet wresting himself free from the allegiances of an overt politics. The entrepreneur is confronted with the messy experience of entrepreneuring, which is far from echoing the heroic figure of the conventional representations of the Schumpeterian entrepreneur. Entrepreneurs, evident in the study by Duymedjian et al. (2019), find themselves in liminal spaces calling for reflexivity and opening the potential for making the entrepreneurial identity as a space for political reflection. In a similar way, Jarrodi et al. (2019) show how social entrepreneurs can draw from different discourses, or political ideologies, sometimes slippery ones, for making sense of the ways they intend to disrupt the status-quo. Jarrodi et al. (2019), seeking to contribute to a demystification of the motivations of social entrepreneurs, offer a framework to 'show how politics can shape social entrepreneurs' motivations'. Social entrepreneurs, in their view, re-open political possibilities by enacting a multiplicity of beliefs, that would be reflected in their 
actions and in the creation of new organizational forms. The study shows that when we use a political ideology lens, social entrepreneurs' relationship to values and their motivations are seen and understood in new ways. Thus, we learn from this study that 'everything changes' when we resist a de-politicized understanding of entrepreneurship. We learn that entrepreneurship is always political and that creation inevitably needs to battle the politics of dominant orders.

This wresting free from dominant orders is never total or complete (cf. Lüthy and Steyaert 2019). Throughout the process of organization-creation studied in the papers, the entrepreneurs are influenced (and sometimes subjugated) by the floating mainstream representations of entrepreneurship. In Riot's (2019) historical study of the $18^{\text {th }}$ century textile manufacturer Christophe-Philippe Oberkampf and the mid $20^{\text {th }}$ Century designers Hans and Florence Knoll we find a plethora of heavily policed entrepreneurial categories being happily absorbed, indeed very little battle for openings in the common. Given the cases are used to assess the cogency of Schumpeter's theoretical framing of creative destruction, the reader is left alive to the need to update and nuance the sense of creativity with which Schumpeter was working.

\section{Future directions}

This special issue, as briefly described above, performs a political act as such. It takes 'special' in 'special issue' as an opening - a crack - in the politics of researching and writing entrepreneurship, and tries to bring those practices into the open. It is a move that initiates a political effort to de-naturalise or de-normalise entrepreneurship, starting by disentangling entrepreneurship from the politics of 
enterprise. This is done on the backdrop of a proposed reading of organisational entrepreneurship as inherently political, in its ability to disrupt and declassify the existing distribution of the sensible (what passes as facts, what already makes sense, who can speak and not only make noise, who can be seen and emerge from the invisible). To some extent, we have contributed to making Rancière visible in entrepreneurship studies, hopefully also achieved to make his philosophy speak and not only pass as noise. Building on a Rancerian perspective we have also tried to make the political in entrepreneurship non-negligible. As a process of creating organisation for the purpose of actualising new values, entrepreneurship is always social, tied to the other, and opening up new possibilities for living. Social entrepreneurship is often more evidently demonstrating this. However, entrepreneurship as corporate venturing or new firm formation is also part of making new value actual, and therefore opening up new possibilities (however trivial they might sometimes be). Entrepreneurship happens in the common, and is thus inescapably political by partaking in redistributing the sensible and hence the production of new possibilities for subjectivity, ways and styles of living, and value.

With Agamben and more so Rancière, two contemporary thinkers that have renewed our understanding of the political, we have also shed light on the ways that entrepreneurship studies might distance itself from the normalized discourse of "enterprise" (Hjorth and Holt 2016) and itself affirm its entrepreneurial politics (Hjorth and Steyaert 2009). The very notion of entrepreneurship as also political is thus intensified when it is related to conflictual disruption, the questioning that creates (temporal) in-between spaces. The 'entre' of entrepreneurship is a space-to-be-made and used, beyond the classified order of things, a potential space of free movement, yet subject to the politics of managing an efficiency-enhancing order. 
Entrepreneurship studies could thus be understood as constantly engaged in a struggle to free itself from inclusion into knowledge-regimes serving the dominant organizational practice of management and its need for control and predictability: "... a world governed by interest offered... a number of specific assets of its own. The most general of these assets was predictability." (Hirschman 1977: 49, emphasis in original). In multiple ways, contributions to this Special Issue bring us insightful studies of entrepreneurship's political challenges. When entrepreneurship's political is unsilenced like this, new needs to make sense of entrepreneurship follow. Contributing papers do respond to this and provide us with novel conceptualisations of entrepreneurship. This is a start, and we hope that by opening up to seeing entrepreneurship as a political process, this allows the student of such processes to see how they produce dislocations, disruptions, and breaks in of the politics of the dominant order, by constantly moving towards the edge of the established. This, we firmly believe, will enrich the future of entrepreneurship studies, whether social-, corporate-, organisational-, or startup focused. There are many yet-to-be-asked research-questions lying in wait as we bring entrepreneurship studies beyond this edge. No doubt, there will be attempts to exclude the political from entrepreneurship. We hope, as you read on, that this Special Issue will further increase your sensibility before the political such that attempts to classify it as 'outside' will be anticipated in time for your creative moves, past the politics of control, exploring the values of a more complex and nuanced entrepreneurship studies. 


\section{References}

Agamben, G. 1998. Homo Sacer. Stanford: Stanford University Press.

Anderson, A. and Warren, L. 2011. "The entrepreneur as hero and jester:

Enacting the entrepreneurial discourse." International Small Business Fournal 29(6): 589-609.

Becker, Gary. 1995. "The Economic Approach to Human Behavior." In The Essence of Becker, edited by Ramón Febrero, R. and Schwartz, P. S., 3-17. Stanford: Hoover Institution Press.

Beyes, T. and Steyaert, C. 2012. "Spacing organization: non-representational theory and performing organizational space." Organization, 19(1): 45-61.

Burgelman, R. A. 1983. "Corporate entrepreneurship and strategic management: insights from a process study." Management Science 29: 1349-1364.

Burnham, J. 1941. The Managerial Revolution, Westport: Greenwood Press Publ.

Butler, J. 1997. The Psychic Life of Power - Theories in Subjection. Stanford: Stanford University Press.

Cooper, M. 2017. Family Values: Between Neoliberalism and the New Social Conservatism. New York: Zone.

Courpasson, D., Dany, F., and Marti, I. 2016. "Organizational Entrepreneurship as 
Active Resistance: A Struggle against Outsourcing." Entrepreneurship, Theory \& Practice $40(1), 131-160$.

Chia R., 1996. Teaching Paradigm Shifting in Management Education: University Busi- ness Schools and the Entrepreneurial Imagination. Journal of Management Studies 33(4): 409-428.

Chun, W. 2019. "Filter systems." in The Oxford Handbook of Media, Technology and Organization Studies, edited by T. Beyes, R. Holt and C. Pias, [no pages yet]. Oxford: Oxford University Press.

Daskalaki, M., Hjorth, D., and Mair, J. 2015. “Are Entrepreneurship, Communities, and Social Transformation Related?." Fournal of Management Inquiry 24 (4), 419-423.

Davis, O. 2010. Jacques Rancière. London: Polity Press.

Deleuze, G. 1988. Spinoza: Practical Philosophy. Transl. by Robert Hurley. San Francisco: City Lights Books.

Deleuze, G. 1995. Negotiations. New York: Columbia University Press.

Deleuze, G. 1998. Essays - critical and clinical, Transl. by Daniel W. Smith and Michael A. Greco, London/New York: Verso. 
Dodd, S., Jack, S., Anderson, A. 2013. "From admiration to abhorrence: The contentious appeal of entrepreneurship across Europe." Entrepreneurship \& Regional Development 25(1-2): 69-89.

Douglas, M. 2003. Purity and danger: An analysis of concepts of pollution and taboo. London: Routledge.

Down, S. 2013. "The distinctiveness of the European tradition in entrepreneurship research.” Entrepreneurship and Regional Development 25(1-2): 1-4.

Du Gay, P. 1991. "Enterprise Culture and the Ideology of Excellence.” New Formations 13: 45-61.

du Gay, P. 2004. "Against enterprise (But not against "enterprise", for that would make no sense)." Organization 11(1): 37-57.

Fleming, P. 2017. "The Human Capital Hoax: Work, Debt and Insecurity in the Era of Uberization", Organization Studies 38(5): 691-709.

Foucault, M. 1982. "The Subject and Power," in Michel Foucault - Beyond Structuralism and Hermeneutics, edited by Dreyfus, H. L. and Rabinow, P., 208-226. London: Harvester Wheatsheat.

Foucault, M. 1994 The birth of the clinic - an archaeology of medical perception. Transl. by A. M. Sheridan Smith. New York: Vintage Books. 
Foucault, M. 2003. Abnormal-lectures at the Collège de France 1974-1975. Edited by Valerio Marchetti and Antonella Salomoni. Transl. by Graham Burchell. New York: Picador.

Foucault, Michel. 2008. Birth of Biopolitics: Lectures at the Collège de France, 1978-1979. Edited by Michel Senellart. Transl. by Graham Burchell. New York: Palgrave Macmillan.

Hirschman, A. O. 1977. The passions and the interests: Political arguments for capitalism before its triumph. Princeton: Princeton University Press.

Hjorth, D. and Steyaert, C. 2009. "Entrepreneurship as disruptive event.” In The politics and Aesthetics of Entrepreneurship, edited by Hjorth, D. and Steyaert, C., 1-10. Cheltenham: Edward Elgar.

Hjorth, D., Holt, R. 2016. "Its entrepreneurship, not enterprise: Ai Weiwei as an entrepreneur." Journal of Business Venturing Insights 5: 50-54.

Hoskin, K. 2006. "Management as product of the European knowledge tradition: a modern form of ancient paidea?" In Management Education and Humanities, edited by P. Gagliardi and B. Czarniawska, 159-173. Cheltenham: Edward Elgar.

Kacperczyk, A. J. 2012. "Opportunity structures in established firms: Entrepreneurship versus Intrapreneurship in Mutual Funds." Administrative Science 
Quarterly. 57(3): 484-521.

Kanter, R. M. 1989. When Giants Learn to Dance. New York: Simon \& Schuster Inc.

Martí, I. and Fernández, P. 2015 "Entrepreneurship, togetherness, and emotions: A look at (Postcrisis) Spain." Fournal of Management Inquiry. 24(4): 424-428.

Massumi, B. 2002. Parables for the Virtual - movement, affect, sensation. Durham: Duke University Press.

Massumi, B. 2015. The Power at the End of Economy. Durham and London: Duke University Press.

May, T (2009) "Rancière in South Carolina." In Facques Rancière - history, politics, aesthetics, edited by Rockhill, G. and Watts, P., 105-119. Durham/London: Duke University Press.

Miller, P. and Rose, N. 1990. "Governing Economic Life." Economy and Society. 19(1): $1-31$.

McNay, L. 2009. "Self as Enterprise: Dilemmas of control and resistance in Foucault's The Birth of Biopolitics." Theory, Culture \& Society. 26(6): 55-77.

Parker, M. 2002. Against Management: Organization in an Age of Managerialism.

London: Polity Press. 
Rancière, J. 1997. Onze thèses sur la politique. Filozofski Vestnik, XVIII, 91-106.

Rancière, J. 1999. Dis-agreement: Politics and Philosophy, Minneapolis: University of Minnesota Press.

Rancière, J. 2004. The politics of aesthetics. The distribution of the sensible. Gabriel Rockhill: London/New York: Continuum.

Reckwitz, A. 2017. The Invention of Creativity. Transl. by Steven Black. Cambridge: Polity.

Rose, N. 2019. Our Psychiatric Future. Cambridge: Polity.

Schumpeter, J. A. 1942. Capitalism, Socialism and Democracy. New York: Harper and Row.

Schumpeter, J. A. 1947. "The Creative Response in Economic History.” Journal of Economic History, Nov: 149-159, in Essays, edited by R. V. Clemence, 221-240. New Brunswick and London: Transaction Publishers.

Skoglund, A. and Böhm, S. 2019 Renewable energy activism. Cambridge Cambridge University Press.

Sturdy, A. and Wright, C. 2008. "A consulting diaspora? Enterprising selves as agents of enterprise.” Organization. 15(3): 427-444 
Swedberg, R. 2012. "Schumpeter's theories of organizational entrepreneurship.” in Handbook on Organisational Entrepreneurship, edited by D. Hjorth, 31-48. Cheltenham: Edward Elgar.

Sørensen, J. B. 2007. "Bureaucracy and entrepreneurship: Workplace effects on entrepreneurial entry." Administrative Science Quarterly. 52: 387-412.

Steyaert, C. and Hjorth, D. eds. 2006. Entrepreneurship as Social Change. Cheltenham: Edward Elgar.

Steyaert, C. and Katz, J. 2004. "Reclaiming the space of entrepreneurship in society: geographical, discursive and social dimensions." Entrepreneurship and Regional Development 16(3): 179-196.

Vallas, S. 2015. “Accounting for precarity: Recent studies of labor market uncertainty". Contemporary Sociology: A Fournal of Reviewes 44(4): 463-469.

Welter, F. and Smallbone, D. 2010. "Institutional perspectives on entrepreneurial behaviour in challenging environments." Fournal of Small Business Management. 49(1): 107-125.

Zahra, S. A., Newey, L. R., and Li, Y. 2014. "On the Frontiers: The Implications of Social Entrepreneurship for International Entrepreneurship.” Entrepreneurship, Theory EP Practice 38(1): 137-158. 